\title{
Anti-Adhesion Therapies in Inflammatory Bowel Disease- Molecular and Clinical Aspects
}

\author{
Sebastian Zundler ${ }^{1}$, Emily Becker ${ }^{1}$, Carl Weidinger ${ }^{2,3}$ and Britta Siegmund ${ }^{2 *}$ \\ ${ }^{1}$ Department of Medicine 1, University of Erlangen-Nuremberg, Translational Research Center, Erlangen, Germany, \\ ${ }^{2}$ Department of Gastroenterology, Infectious Diseases and Rheumatology, Charité-University Medicine, Berlin, Germany, \\ ${ }^{3}$ Berlin Institute of Health, Berlin, Germany
}

\section{OPEN ACCESS}

Edited by:

Marcello Chieppa, IRCCS "de Bellis",

Italy

Reviewed by: Anastasia Sobolewski, University of East Anglia, United Kingdom Luca Pastorelli, Università degli Studi di Milano, Italy

*Correspondence: Britta Siegmund britta.siegmund@charite.de

Specialty section: This article was submitted to Mucosal Immunity, a section of the journal Frontiers in Immunology

Received: 29 May 2017 Accepted: 12 July 2017 Published: 28 July 2017

Citation:

Zundler S, Becker E, Weidinger C and Siegmund B (2017) AntiAdhesion Therapies in Inflammatory Bowel Disease-Molecular and Clinical Aspects.

Front. Immunol. 8:891. doi: 10.3389/fimmu.2017.00891
The number of biologicals for the therapy of immunologically mediated diseases is constantly growing. In contrast to other agents that were previously introduced in rheumatologic or dermatologic diseases and only later adopted for the treatment of inflammatory bowel diseases (IBDs), the field of IBD was ground breaking for the concept of anti-adhesion blockade. Anti-adhesion antibodies selectively target integrins controlling cell homing to the intestine, which leads to reduction of inflammatory infiltration to the gut in chronic intestinal inflammation. Currently, the anti- $\alpha 4 \beta 7$-antibody vedolizumab is successfully used for both Crohn's disease and ulcerative colitis worldwide. In this mini-review, we will summarize the fundamental basis of intestinal $T$ cell homing and explain the molecular groundwork underlying current and potential future anti-adhesion therapies. Finally, we will comment on noteworthy clinical aspects of anti-adhesion therapy and give an outlook to the future of anti-integrin antibodies and inhibitors.

Keywords: inflammatory bowel diseases, ulcerative colitis, Crohn's disease, vedolizumab, natalizumab, etrolizumab, gut homing, integrins

\section{INTRODUCTION}

Inflammatory bowel diseases (IBDs), such as Crohn's disease (CD) and ulcerative colitis (UC), are characterized by chronically relapsing inflammation of the gut and are associated with considerable morbidity and reduced quality of life (1). The pathogenesis of IBD is still incompletely understood. However, environmental factors, genetic susceptibility, changes in the intestinal microbiome, and altered immune signaling in the gut have been identified to play an essential role during IBD development $(2,3)$. In particular, infiltration of various immune cells in the inflamed gut in IBD is a prominent feature of both CD and UC. These cells are targeted by most "traditional" IBD therapies including immunosuppressive agents and anti-tumor necrosis factor (TNF) antibodies. Yet, a significant portion of patients does not respond to such therapies, loses response or experiences side effects, underscoring the need for additional treatment concepts.

One such concept is anti-adhesion therapy. T lymphocytes are a crucial part of the intestinal immune $(4,5)$ system, and their numbers are mainly controlled by the balance of proliferation and apoptosis $(6,7)$ as well as by cell recruitment of circulating $\mathrm{T}$ cells from the bloodstream. The clinical use of antibodies like natalizumab or vedolizumab, which block surface molecules on $\mathrm{T}$ cells called integrins regulating their capacity to home to the gut, has conferred considerable attraction to intestinal $\mathrm{T}$ cell trafficking and the concept of anti-adhesion therapies. Meanwhile, several additional antibodies and compounds targeting distinct $\mathrm{T}$ cell trafficking steps are under 
development, and one or the other might soon contribute to a growing family of anti-trafficking drugs for the treatment of IBD.

In this mini-review, we will give an overview of the basic principles underlying intestinal $\mathrm{T}$ cell trafficking and summarize the translational relevance of these principles by highlighting the most important molecular and clinical aspects of current and future anti-adhesion therapies.

\section{MECHANISMS OF T CELL TRAFFICKING}

A central event in the pathogenesis of $\mathrm{T}$ cell-dependent chronic intestinal inflammation is the homing of $\mathrm{T}$ lymphocytes to the gut (Figure 1). Homing describes a multistep process consisting of cell tethering to and rolling along activated endothelial cells, subsequent activation and firm adhesion of T cells, finally leading to their para- or transcellular transmigration from high endothelial venules (HEVs) into the tissue (8). To ensure that antigen-experienced $\mathrm{T}$ cells can reach their designated destination, a "zip code" like system of specific molecules controls homing to the intestinal lamina propria (LP). The expression of these molecules is primed during activation and expansion of naïve $\mathrm{T}$ cells after contact with their cognate antigen in the gut-associated lymphoid tissues. There, dendritic cells (DCs) (9), characterized by expression of CD103, not only present intestinal antigens to $\mathrm{T}$ cells and co-stimulate them, if applicable, but also produce retinoic acid (RA) through retinal aldehyde dehydrogenase. RA leads to upregulation of unique gut-homing markers including the integrin $\alpha 4 \beta 7$ and CC-chemokine receptor (CCR) 9 and, in turn, to loss of naïve $\mathrm{T}$ cell homing markers such as CCR7 (10-12).

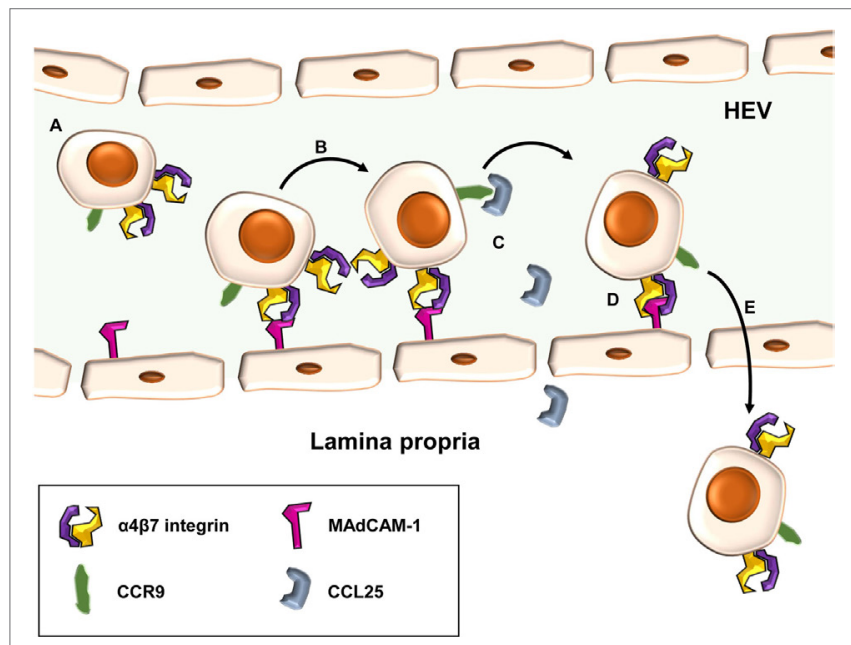

FIGURE 1 | Principle of $\alpha 4 \beta 7$-mediated cell adhesion in the intestine. Gut-homing T cells carrying the $\alpha 4 \beta 7$ integrin and CC-chemokine receptor (CCR) 9 (A) may role along high endothelial venules (HEVs) of the gut by low-affinity interactions of $\alpha 4 \beta 7$ with mucosal vascular addressin cell adhesion molecule (MAdCAM)-1 (B). Upon CCR signaling, e.g., via CC-chemokine ligand (CCL)-25 and CCR9 (C), integrin-affinity modulation of $\alpha 4 \beta 7$ allows tight interaction with MAdCAM- 1 and leads to firm adhesion of cells at the endothelial wall (D). Subsequently, T cells may home para- or transcellularly to the lamina propria (E).
After this switch in integrin expression, primed $\mathrm{T}$ cells can leave lymphoid organs to reenter the systemic circulation and adhere to intestinal HEVs expressing the addressin mucosal vascular addressin cell adhesion molecule (MAdCAM)-1 (13). MAdCAM- 1 is the natural interaction partner of $\alpha 4 \beta 7$ integrin and, thus recognizing the "zip code" of gut-homing T cells (14). Unlike constitutively expressed selectins, integrins on T cells have to be activated in a process known as integrin-affinity modulation, before they can establish firm binding (15). This results in a conformation highly affinitive for the respective addressin. In contrast to other organs, where rolling is mainly mediated by selectins, weak and dynamic interactions of the low-affinity conformation of $\alpha 4 \beta 7$ with MAdCAM- 1 are sufficient to induce tethering and rolling of T cells in the gut.

Rolling reduces the velocity of circulating $\mathrm{T}$ cells in the blood stream creating the basis for further homing and transmigration steps. Affinity modulation required for conformational change of $\alpha 4 \beta 7$ to its high-affinity state and subsequent firm adhesion is initiated by cell activation through chemokine receptor signaling. For instance, the CCL-25 secreted by LP cells in the small intestine, binds to CCR9, which is specifically expressed on gut-homing T cells. Subsequently, integrin heterodimers change from a folded position, in which the headpiece of the molecules is bent toward the plasma membrane and the addressin binding pocket is hidden, to an open conformation increasing not only the accessibility of the binding domain but also fully opening the pocket and enhancing its affinity $(15,16)$.

In addition to $\alpha 4 \beta 7$, other integrins like $\alpha 4 \beta 1$ may also contribute to adhesion of T cells to intestinal HEVs (17). Upon firm arrest of T cells, interactions of integrins with junctional adhesion molecules expressed on HEV s like JAM-1 contribute to para- or transcellular extravasation into the inflamed tissue (18).

Once homed to the gut, $\mathrm{T}$ cells contribute to immunological events depending on their designated role, such as T helper (Th) 1, Th2, Th9, Th17, cytotoxic T cells, or regulatory T cells (Tregs). However, trafficking of these cells is not necessarily finished, e.g., CCR7-dependent recirculation via lymphatic vessels (19) or sphingosine-1 phosphate-dependent exit to the blood stream has been described (20) and is reviewed elsewhere (21). Moreover, transforming growth factor $\beta$ may trigger the upregulation of $\alpha \mathrm{E} \beta 7$ integrin, which cooperates with E-cadherin in the gut epithelial layer retaining $\mathrm{T}$ cells in or near the epithelium $(22,23)$.

It has been recognized more than two decades ago that all these mechanisms are not only academically interesting but also translationally relevant and allow targeted interference with the gut-homing process. Accordingly, targeted treatments for IBD interfering with the gut homing process have been developed and molecular and clinical aspects of these therapies will be discussed in the following paragraphs.

\section{MOLECULAR ASPECTS OF ANTI-ADHESION THERAPIES}

T cell trafficking includes a multitude of events such as priming, homing, recirculation, or retention, and all these steps are potential targets of therapy. So far, strategies impeding 
integrin-dependent cell adhesion to addressins have been most successful (24), and we will thus focus on these anti-adhesion therapies. Most importantly, the anti- $\alpha 4$-antibody natalizumab and the anti- $\alpha 4 \beta 7$-antibody vedolizumab reached clinical approval after large phase III studies (25-27).

Yet, the divergent fate of these antibodies illustratively underscores redundancies and specificities (Figure 2) in integrindependent homing to the gut and other organs, based on the heterodimeric composition of integrins. An $\alpha$ and a $\beta$ chain pair form an $\alpha \beta$ heterodimer with most single chains combining with different other chains to form several distinct heterodimers. Thus, targeting integrins by antibodies on the monomer and heterodimer level results in coverage of a set of integrins or only one specific representative, respectively.

Both anti- $\alpha 4$ and anti- $\alpha 4 \beta 7$ strategies were initially evaluated in the cotton-top tamarine model of colitis, where they protected these animals from UC-like disease $(28,29)$, prior to testing of humanized antibodies in clinical trials. Soon after approval of natalizumab for $\mathrm{CD}$, a report of progressive multifocal leukoencephalopathy (PML) was published (30), a severe infectious side effect deemed to arise from concurrent inhibition of $\alpha 4 \beta 1$-dependent homing via vascular cell adhesion molecule (VCAM)-1 to the central nervous system (31). Consistently, this has led to strong limitation or complete abandoning of natalizumab use in CD. On the other hand and matching with the current knowledge about $\mathrm{T}$ cell homing, vedolizumab, which

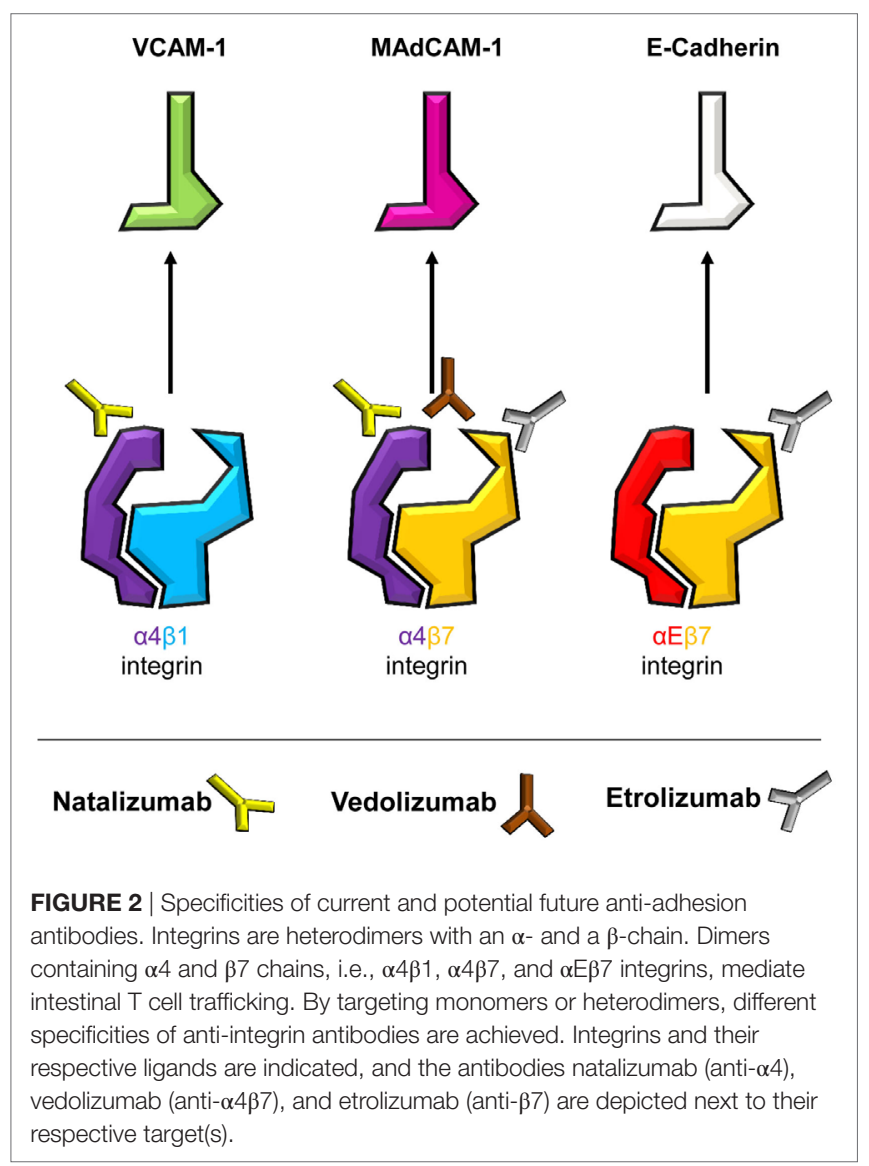

is specific for the $\alpha 4 \beta 7$ heterodimer, has been successfully used for the treatment of both CD and UC for several years $(32,33)$ and has not been associated with infectious side effects in the central nervous system. The higher specificity of vedolizumab, however, also results in missing out alternative homing pathways as demonstrated by a study suggesting that homing via $\alpha 4 \beta 1$ might at least partially compensate for $\alpha 4 \beta 7$ blockade in CD patients treated with vedolizumab (17).

With the ongoing clinical studies of the anti- $\beta 7$-antibody etrolizumab we are currently facing a new attempt to block $\alpha 4 \beta 7$ together with another integrin (34). Pan- $\beta 7$ inhibition provides hopes that dual targeting of $\alpha \mathrm{E} \beta 7$ and $\alpha 4 \beta 7$ might increase therapeutic effects by additionally blocking intestinal retention of pathogenic $\mathrm{T}$ cells through E-cadherin (35). However, less gut specificity might be observed with $\beta 7$ blockade since $\alpha E \beta 7$ is also expressed by T cells in other tissues and might be important for the control of local infections there $(36,37)$. It will thus be an important task to determine potential infectious side effects of etrolizumab in the ongoing phase III trials. Moreover, it is not clear, whether anti- $\beta 7$ antibodies impact $\mathrm{CD}_{103^{+}}$intestinal DCs (38). Since such DCs were proposed to be responsible for the induction of Tregs with anti-inflammatory properties under homeostatic conditions (39), it cannot be excluded that pan $\beta 7$ inhibition reduces intestinal Treg cell numbers. However, it has also been shown that intestinal inflammation alters the role of these DCs switching their function to inducers of effector-like $\mathrm{T}$ cells (40), thus rather suggesting that anti- $\beta 7$ treatment could help to reduce inflammation beyond the $\mathrm{T}$ cell level.

Taken together, the molecular mechanisms of targeting $\alpha 4$, $\alpha 4 \beta 7$, or $\beta 7$ integrins in IBD show that it is not easy to find the optimum between the poles of maximally efficient gut homing blockade (i.e., inhibition of a plurality of responsible molecules) and selectivity (i.e., maximum safety). Therefore, further translational and empirical research is needed for elucidation of these challenging questions.

Such considerations get even more complicated when also taking the addressin side into account. Regarding the success of $\alpha 4 \beta 7$ inhibition, it seems logical that antibodies to MAdCAM-1 should result in similar clinical benefit. Yet, this black-and-white thinking does not match the myriads of grayscales in human biology since $\alpha 4 \beta 7$ is not only cooperating with MAdCAM-1 but also contains epitopes to bind to VCAM-1 and to fibronectin (41). This might be one explanation for the impression provided by early clinical studies that anti-MAdCAM-1 might not be as effective as vedolizumab $(42,43)$, although it has been claimed that vedolizumab does not interfere with $\alpha 4 \beta 7$ binding to VCAM-1 (41).

Another interesting molecular aspect of anti-adhesion therapies that is only beginning to be understood is the marked difference in the expression of integrins like $\alpha 4 \beta 7$ and $\alpha E \beta 7$ on specific Th cell populations $(35,44)$. While Th2 and Th17 cells seem to express high levels of $\alpha 4 \beta 7$, Th1 and Th9 cells have low expression of $\alpha 4 \beta 7$. In contrast, $\alpha \mathrm{E} \beta 7$ is high in Th9 and Th17 but low in Th2 and Th1 cells (35). Since it is considered that CD is marked by Th1 and UC by Th2-like signaling $(4,45)$, differential expression of $\alpha 4 \beta 7$ might be one piece in the puzzle to 
explain, why the proportion of UC patients responding to treatment with vedolizumab seems to be higher compared with $C D$ $(25,26)$. Moreover, it seems possible that assessment of individual or disease-specific Th cell profiles might help to optimize treatment by choosing antibodies most closely covering the respective subsets.

In conclusion, our understanding of the molecular mechanisms of gut homing has facilitated the development of novel therapies for IBD, but we are far away from a profound conceptual comprehension that includes an exact perception of the role of integrins and addressins in different tissues, with regard to different cellular subpopulations and concerning less prominent or rather overlooked "cross-interactions" between different homing pathways.

\section{CLINICAL ASPECTS OF ANTI-ADHESION THERAPIES}

Blocking the migration of inflammatory cells into the target tissue is, as outlined earlier, an intriguing concept. The field was clinically implemented with the $\alpha 4$-antibody natalizumab. Clinical efficacy was proven first in a pilot study in CD (46), and subsequently in a phase III trial $(47,48)$. Here, patients with moderate to severe $\mathrm{CD}$ and an increase in C-reactive protein were randomized to receive $300 \mathrm{mg}$ natalizumab or placebo at weeks 0,4 , and 8 . Response by week 8 , as indicated by a $\geq 70$ point decrease from baseline in the $\mathrm{CD}$ activity index, sustained through week 12 in $48 \%$ of natalizumab-treated patients and in $32 \%$ of placebo-treated patients. This was statistically highly significant, and hence the primary endpoint of the study was met (48). These observations led to the approval of natalizumab for CD in North America. The enthusiasm for $\alpha 4$ blockade came to a sudden halt, when a fatal JC virus-related PML was reported upon natalizumab treatment (30), preventing the drug from approval in the European Union. The explanation for this side effect is rather obvious since anti- $\alpha 4$ equally hinders $\alpha 4 \beta 1^{+}$ immune cells from not only infiltrating the gut but also the brain, hence impeding appropriate cerebral antiviral immunity.

Subsequently, the field moved on by developing more specific anti-adhesion strategies. The first and at this point only one with EMA approval for IBDs is the $\alpha 4 \beta 7$-antibody vedolizumab. Two large phase III trials led to approval (Table 1) $(25,26)$. Briefly summarized for UC, the primary endpoint at week 6 , clinical response, showed significant differences $(47.1 \%$ vedolizumab group vs. $25.5 \%$ placebo group) (25). Of the patients who responded to induction therapy at week $6,88 \%$ were in remission after 104 weeks and 96\% after 152 weeks of treatment (49). In $\mathrm{CD}$, clinical remission showed a significant difference at week 6 (14.5\% vedolizumab group vs. $6.8 \%$ placebo group) (26). Of all patients responding in week 6 who received vedolizumab continuously, 83 and $89 \%$ of patients were in remission after 104 and 152 weeks, respectively (50).

Besides these, initial phase III trials several real life registries from various countries have reported comparable efficacy $(34,49,50,52,53)$.

In a German cohort with 212 consecutive patients with either CD or UC, clinical remission at week 14 was assessed (33). 23.7\%
TABLE 1 | Overview of clinical data from randomized-controlled studies on natalizumab, vedolizumab and etrolizumab in CD and UC.

\begin{tabular}{|c|c|c|c|}
\hline & \multicolumn{2}{|c|}{ Efficacy } & \multirow{2}{*}{$\begin{array}{l}\text { Important safety } \\
\text { aspects }\end{array}$} \\
\hline & CD & UC & \\
\hline Natalizumab & $\begin{array}{l}\text { Phase III: + } 16 \% \text { clinical } \\
\text { response after } 8 \text { weeks } \\
\text { vs. placebo (in patients } \\
\text { with elevated CRP) (48) }\end{array}$ & & $\begin{array}{l}\text { Risk of PML } \\
(30)\end{array}$ \\
\hline Vedolizumab & $\begin{array}{l}\text { Phase III: }+7.7 \% \\
\text { clinical remission after } \\
6 \text { weeks vs. placebo } \\
(26)\end{array}$ & $\begin{array}{l}\text { Phase III: } \\
+21.6 \% \text { clinical } \\
\text { response after } \\
6 \text { weeks vs. } \\
\text { placebo (25) }\end{array}$ & $\begin{array}{l}\text { Nasopharyngitis, } \\
\text { surgical site } \\
\text { infection? } \\
(25,26,51)\end{array}$ \\
\hline Etrolizumab & & $\begin{array}{l}\text { Phase II: }+21 \% \\
\text { clinical remission } \\
\text { after } 10 \text { weeks } \\
\text { vs. placebo (34) }\end{array}$ & $\begin{array}{l}\text { Influenza-like illness, } \\
\text { arthralgia, and rash } \\
\text { (34) }\end{array}$ \\
\hline
\end{tabular}

Differences in the primary endpoint vs. placebo group are indicated, and most important side effects are noted. See text for details.

$C D$, Crohn's disease; UC, ulcerative colitis; $C R P, C$-reactive protein; $P M L$, progressive multifocal leukoencephalopathy.

of patients with $\mathrm{CD}$ and $23.5 \%$ with UC achieved clinical remission. One has to recognize that during the initial time period after approval mostly more refractory patients were exposed to vedolizumab. The cohort was then followed for 30 and 54 weeks, respectively, and included $67 \mathrm{CD}$ and 60 UC patients. Primary endpoint was clinical remission at week 54, which was achieved in $21 \%$ of CD and $25 \%$ of UC patients, respectively (54).

It should also be mentioned that in comparison with anti-TNF antibodies, it seems that vedolizumab needs longer to manifest full effects $(25,26,55)$. Regarding the abovementioned mechanistic aspects, it is tempting to speculate that this might be due to preserved function of T cells already present in the LP during the initial phase of vedolizumab treatment, while homing inhibition might only then lead to marked effects on T cell function, when a significant portion of these LP T cells undergoes apoptosis and replenishment is impeded.

Several other strategies are currently under clinical investigation including the anti- $\beta 7$-antibody etrolizumab where a recent phase II trial for UC showed promising results and initiated a broad phase III study program (34). In a double-blind, placebocontrolled, randomized, phase II study including patients with moderately to severely active UC that did not respond to conventional treatment were randomized (1:1:1) to receive either etrolizumab $100 \mathrm{mg}$ at week 0,4 , and 8 with placebo at week 2 , $420 \mathrm{mg}$ etrolizumab loading dose at week 0 followed by $300 \mathrm{mg}$ at weeks 2, 4, and 8 or placebo. 124 patients were included and none of the placebo group patients reached the primary endpoint of clinical remission at week 10 , whereas $21 \%$ of the etrolizumab $100 \mathrm{mg}$ group and $12 \%$ in the $300 \mathrm{mg}$ group met the endpoint. The authors conclude that etrolizumab showed clinical efficacy and hence $\alpha 4 \beta 7$ as well as $\alpha E \beta 7$ might provide future therapeutic targets. Beside efficacy, the remarkable part of the study was that it provided for the first time a predictive biomarker for the responsiveness to an anti-inflammatory biological since $\alpha \mathrm{E}$ expression in the intestinal mucosa correlated with a better response to 
etrolizumab treatment (34). In a follow-up study, these findings were specified and showed that high granzyme $\mathrm{A}$ and $\alpha \mathrm{E}$ mRNA expression levels in colon biopsies revealed patients with UC more likely to respond to etrolizumab treatment (56).

Several other strategies target migration; one is approaching MAdCAM-1 on the endothelial site. A first dose-finding study indicated safety and efficacy in patients with UC (57). Very recently, the results of a phase II follow-up study were published. In this trial, patients were treated with subcutaneous injections of one of four doses $(7.5,22.5,75$, or $225 \mathrm{mg}$ ) of the anti-MAdCAM-1 antibody PF-00547659 or placebo. The primary endpoint was remission at week 12 . This was met in three of the four verum groups $(7.5,22.5$, or $75 \mathrm{mg})$, the highest difference in efficacy compared to placebo was observed in the $22.5 \mathrm{mg}$ group (58).

\section{SAFETY}

After the fatal complications observed under natalizumab treatment, none of the other strategies currently approved or studied revealed a new case of PML. A recent publication summarizes the collected safety data (May 2009-June 2013) from six studies of vedolizumab. Any patient that received $\geq 1$ infusion of vedolizumab or placebo was included, and results were expressed as exposure-adjusted incidence rates with the number of patients experiencing the event per 100 person-years of exposure. The analysis included 2,830 patients with 4,811 person-years of exposure. Remarkably, no increased risk for any infection was associated with vedolizumab. Most important, up-to-date, no case of PML has been reported within this review or outside (59). The limitation of the study is the number of patients, while 2,789 had been exposed to $\geq 1$ dose of vedolizumab, only 906 were exposed for $\geq 24$ months and only 40 were exposed for $\geq 48$ months (59).

Somewhat surprisingly, extra-intestinal symptoms in patients receiving vedolizumab are observed and are more common in

\section{REFERENCES}

1. Lönnfors S, Vermeire S, Avedano L. IBD and health-related quality of lifediscovering the true impact. J Crohns Colitis (2014) 8:1281-6. doi:10.1016/j. crohns.2014.03.005

2. Jostins L, Ripke S, Weersma RK, Duerr RH, McGovern DP, Hui KY, et al. Hostmicrobe interactions have shaped the genetic architecture of inflammatory bowel disease. Nature (2012) 491:119-24. doi:10.1038/nature11582

3. Siegmund B, Zeitz M. Clinical aspects of inflammatory bowel disease. Eur J Immunol (2009) 39:2026-30. doi:10.1002/eji.200939601

4. Neurath MF. Cytokines in inflammatory bowel disease. Nat Rev Immunol (2014) 14:329-42. doi:10.1038/nri3661

5. Shih DQ, Targan SR, McGovern D. Recent advances in IBD pathogenesis: genetics and immunobiology. Curr Gastroenterol Rep (2008) 10:568-75. doi:10.1007/s11894-008-0104-x

6. Monteleone G, Caprioli F. T-cell-directed therapies in inflammatory bowel diseases. Clin Sci (Lond) (2010) 118:707-15. doi:10.1042/CS20100027

7. Sturm A, de Souza HSP, Fiocchi C. Mucosal T cell proliferation and apoptosis in inflammatory bowel disease. Curr Drug Targets (2008) 9:381-7. doi:10.2174/138945008784221198

8. Ley K, Laudanna C, Cybulsky MI, Nourshargh S. Getting to the site of inflammation: the leukocyte adhesion cascade updated. Nat Rev Immunol (2007) 7:678-89. doi:10.1038/nri2156 those patients who respond to therapy (60). Recent data indicate that a shift in integrin expression under $\alpha 4 \beta 7$ neutralization toward a $\beta 1$ upregulation results in an altered migrational behavior of immune cells in non-intestinal tissue including skin, joints, and lung $(61,62)$.

\section{CONCLUSION AND OUTLOOK}

The discussed data indicate that anti-migrational strategies have found their way into clinical practice and the development of further anti-adhesion compounds together with other concepts like Janus kinase inhibitors, anti-IL-23p19 antibodies, or Smad7 blockade might provide optimized IBD treatment in the future. However, as outlined in the first paragraphs of this mini-review, a more detailed understanding of localized integrin expression is required to perform a more personalized treatment and identify the responding patients early on. However, first data indicate that this might become feasible.

\section{AUTHOR CONTRIBUTIONS}

SZ, EB, CW, and BS jointly wrote the manuscript and approved the final version.

\section{FUNDING}

SZ acknowledges funding by the Else Kröner-Stiftung, the Interdisciplinary Center for Clinical Research (IZKF), and the ELAN program of the University Erlangen-Nuremberg. CW acknowledges funding by the Berlin Institute of Health and the German Research Foundation (DFG). BS acknowledges funding by the DFG, the Deutsche Krebshilfe, and the Berlin Institute of Health. The authors acknowledge support by Deutsche Forschungsgemeinschaft and Friedrich-Alexander-Universität Erlangen-Nürnberg (FAU) within the funding program Open Access Publishing.

9. Mora JR, Bono MR, Manjunath $\mathrm{N}$, Weninger W, Cavanagh LL, Rosemblatt M, et al. Selective imprinting of gut-homing T cells by Peyer's patch dendritic cells. Nature (2003) 424:88-93. doi:10.1038/nature01726

10. Iwata M, Hirakiyama A, Eshima Y, Kagechika H, Kato C, Song S-Y. Retinoic acid imprints gut-homing specificity on T cells. Immunity (2004) 21:527-38 doi:10.1016/j.immuni.2004.08.011

11. Mora JR. Homing imprinting and immunomodulation in the gut: role of dendritic cells and retinoids. Inflamm Bowel Dis (2008) 14:275-89. doi:10.1002/ ibd. 20280

12. von Andrian UH, Mackay CR. T-cell function and migration-two sides of the same coin. N Engl J Med (2000) 343:1020-34. doi:10.1056/ NEJM200010053431407

13. Briskin M, Winsor-Hines D, Shyjan A, Cochran N, Bloom S, Wilson J, et al. Human mucosal addressin cell adhesion molecule-1 is preferentially expressed in intestinal tract and associated lymphoid tissue. Am JPathol (1997) 151:97-110.

14. Berlin C, Berg EL, Briskin MJ, Andrew DP, Kilshaw PJ, Holzmann B, et al. Alpha 4 beta 7 integrin mediates lymphocyte binding to the mucosal vascular addressin MAdCAM-1. Cell (1993) 74:185-95. doi:10.1016/0092-8674(93) 90305-A

15. Montresor A, Toffali L, Constantin G, Laudanna C. Chemokines and the signaling modules regulating integrin affinity. Front Immunol (2012) 3:127. doi:10.3389/fimmu.2012.00127 
16. Luo B-H, Carman CV, Springer TA. Structural basis of integrin regulation and signaling. Annu Rev Immunol (2007) 25:619-47. doi:10.1146/annurev. immunol.25.022106.141618

17. Zundler S, Fischer A, Schillinger D, Binder M-T, Atreya R, Rath T, et al. The $\alpha 4 \beta 1$ homing pathway is essential for ileal homing of Crohn's disease effector T cells in vivo. Inflamm Bowel Dis (2017) 23:379-91. doi:10.1097/ MIB.0000000000001029

18. Ostermann G, Weber KSC, Zernecke A, Schröder A, Weber C. JAM-1 is a ligand of the $\beta 2$ integrin LFA-1 involved in transendothelial migration of leukocytes. Nat Immunol (2002) 3:151-8. doi:10.1038/ni755

19. Bromley SK, Thomas SY, Luster AD. Chemokine receptor CCR7 guides T cell exit from peripheral tissues and entry into afferent lymphatics. Nat Immunol (2005) 6:895-901. doi:10.1038/ni1240

20. Mandala S, Hajdu R, Bergstrom J, Quackenbush E, Xie J, Milligan J, et al. Alteration of lymphocyte trafficking by sphingosine-1-phosphate receptor agonists. Science (2002) 296:346-9. doi:10.1126/science.1070238

21. Zundler S, Neurath MF. Novel insights into the mechanisms of gut homing and antiadhesion therapies in inflammatory bowel diseases. Inflamm Bowel Dis (2017) 23:617-27. doi:10.1097/MIB.0000000000001067

22. Cepek KL, Parker CM, Madara JL, Brenner MB. Integrin alpha E beta 7 mediates adhesion of T lymphocytes to epithelial cells. J Immunol (1993) 150:3459-70

23. Gorfu G, Rivera-Nieves J, Ley K. Role of $\beta 7$ integrins in intestinal lymphocyte homing and retention. Curr Mol Med (2009) 9:836-50. doi:10.2174/ 156652409789105525

24. Lobatón T, Vermeire S, Van Assche G, Rutgeerts P. Review article: antiadhesion therapies for inflammatory bowel disease. Aliment Pharmacol Ther (2014) 39:579-94. doi:10.1111/apt.12639

25. Feagan BG, Rutgeerts P, Sands BE, Hanauer S, Colombel J-F, Sandborn WJ, et al. Vedolizumab as induction and maintenance therapy for ulcerative colitis. N Engl J Med (2013) 369:699-710. doi:10.1056/NEJMoa1215734

26. Sandborn WJ, Feagan BG, Rutgeerts P, Hanauer S, Colombel J-F, Sands BE, et al. Vedolizumab as induction and maintenance therapy for Crohn's disease. N Engl J Med (2013) 369:711-21. doi:10.1056/ NEJMoa1215739

27. Sandborn WJ, Colombel JF, Enns R, Feagan BG, Hanauer SB, Lawrance IC, et al. Natalizumab induction and maintenance therapy for Crohn's disease. N Engl J Med (2005) 353:1912-25. doi:10.1056/NEJMoa043335

28. Podolsky DK, Lobb R, King N, Benjamin CD, Pepinsky B, Sehgal P, et al. Attenuation of colitis in the cotton-top tamarin by anti-alpha 4 integrin monoclonal antibody. JClin Invest (1993) 92:372-80. doi:10.1172/ JCI116575

29. Hesterberg P, Winsor-Hines D, Briskin M, Soler-Ferran D, Merrill C, Mackay C, et al. Rapid resolution of chronic colitis in the cotton-top tamarin with an antibody to a gut-homing integrin alpha 4 beta 7. Gastroenterology (1996) 111:1373-80. doi:10.1053/gast.1996.v111.pm8898653

30. Van Assche G, Van Ranst M, Sciot R, Dubois B, Vermeire S, Noman M, et al. Progressive multifocal leukoencephalopathy after natalizumab therapy for Crohn's disease. N Engl J Med (2005) 353:362-8. doi:10.1056/NEJMoa051586

31. Siegmund B. Targeted therapies in inflammatory bowel disease. Dig Dis (2009) 27:465-9. doi:10.1159/000233284

32. Amiot A, Grimaud J-C, Peyrin-Biroulet L, Filippi J, Pariente B, Roblin X, et al. Effectiveness and safety of vedolizumab induction therapy for patients with inflammatory bowel disease. Clin Gastroenterol Hepatol (2016) 14:1593-601. doi:10.1016/j.cgh.2016.02.016

33. Baumgart DC, Bokemeyer B, Drabik A, Stallmach A, Schreiber S; Vedolizumab Germany Consortium. Vedolizumab induction therapy for inflammatory bowel disease in clinical practice - a nationwide consecutive German cohort study. Aliment Pharmacol Ther (2016) 43:1090-102. doi:10.1111/apt.13594

34. Vermeire S, O’Byrne S, Keir M, Williams M, Lu TT, Mansfield JC, et al. Etrolizumab as induction therapy for ulcerative colitis: a randomised, controlled, phase 2 trial. Lancet (2014) 384:309-18. doi:10.1016/ S0140-6736(14)60661-9

35. Zundler S, Schillinger D, Fischer A, Atreya R, López-Posadas R, Watson A, et al. Blockade of $\alpha E \beta 7$ integrin suppresses accumulation of CD8+ and Th9 lymphocytes from patients with IBD in the inflamed gut in vivo. Gut (2016). doi:10.1136/gutjnl-2016-312439
36. Piet B, de Bree GJ, Smids-Dierdorp BS, van der Loos CM, Remmerswaal EBM, von der Thüsen $\mathrm{JH}$, et al. $\mathrm{CD}^{+} \mathrm{T}$ cells with an intraepithelial phenotype upregulate cytotoxic function upon influenza infection in human lung. J Clin Invest (2011) 121:2254-63. doi:10.1172/JCI44675

37. Masson F, Calzascia T, Berardino-Besson WD, de Tribolet N, Dietrich P-Y, Walker PR. Brain microenvironment promotes the final functional maturation of tumor-specific effector CD8+ T cells. J Immunol (2007) 179:845-53. doi:10.4049/jimmunol.179.2.845

38. Annacker O, Coombes JL, Malmstrom V, Uhlig HH, Bourne T, JohanssonLindbom B, et al. Essential role for CD103 in the T cell-mediated regulation of experimental colitis. JExp Med (2005) 202:1051-61. doi:10.1084/ jem.20040662

39. Coombes JL, Siddiqui KRR, Arancibia-Cárcamo CV, Hall J, Sun C-M, Belkaid Y, et al. A functionally specialized population of mucosal CD103+ DCs induces Foxp3+ regulatory $\mathrm{T}$ cells via a TGF- $\beta$ - and retinoic acid-dependent mechanism. J Exp Med (2007) 204:1757-64. doi:10.1084/ jem. 20070590

40. Laffont S, Siddiqui KRR, Powrie F. Intestinal inflammation abrogates the tolerogenic properties of MLN CD103+ dendritic cells. Eur J Immunol (2010) 40:1877-83. doi:10.1002/eji.200939957

41. Soler D, Chapman T, Yang L-L, Wyant T, Egan R, Fedyk ER. The binding specificity and selective antagonism of vedolizumab, an anti- $\alpha 4 \beta 7$ integrin therapeutic antibody in development for inflammatory bowel diseases. J Pharmacol Exp Ther (2009) 330:864-75. doi:10.1124/jpet.109.153973

42. Vermeire S, Sandborn W, Danese S, Hebuterne X, Salzberg B, Klopocka M, et al. OP021. TURANDOT: a randomized, multicenter double-blind, placebocontrolled study of the safety and efficacy of anti-MAdCAM antibody PF-00547659 (PF) in patients with moderate to severe ulcerative colitis (UC). J Crohns Colitis (2015) 9:S13-13. doi:10.1093/ecco-jcc/jju027.021

43. D'Haens G, Lee S, Tarabar D, Louis E, Klopocka M, Park DI, et al. OP022. AntiMAdCAM-1 antibody (PF-00547659) for active refractory Crohn's disease: results of the OPERA study. JCrohns Colitis (2015) 9:S14-14. doi:10.1093/ ecco-jcc/jju027.022

44. Lamb CA, Mansfield JC, Tew GW, Gibbons D, Long AK, Irving P, et al. $\alpha E \beta 7$ integrin identifies subsets of pro-inflammatory colonic $\mathrm{CD} 4+\mathrm{T}$ lymphocytes in ulcerative colitis. J Crohns Colitis (2016) 11:610-20. doi:10.1093/ecco-jcc/ jjw189

45. Gerlach K, Hwang Y, Nikolaev A, Atreya R, Dornhoff H, Steiner S, et al. TH9 cells that express the transcription factor PU.1 drive T cell-mediated colitis via IL-9 receptor signaling in intestinal epithelial cells. Nat Immunol (2014) 15:676-86. doi:10.1038/ni.2920

46. Gordon FH, Lai CW, Hamilton MI, Allison MC, Srivastava ED, Fouweather MG, et al. A randomized placebo-controlled trial of a humanized monoclonal antibody to alpha4 integrin in active Crohn's disease. Gastroenterology (2001) 121:268-74. doi:10.1053/gast.2001.26260

47. Ghosh S, Goldin E, Gordon FH, Malchow HA, Rask-Madsen J, Rutgeerts P, et al. Natalizumab for active Crohn's disease. N Engl J Med (2003) 348:24-32. doi:10.1056/NEJMoa020732

48. Targan SR, Feagan BG, Fedorak RN, Lashner BA, Panaccione R, Present DH, et al. Natalizumab for the treatment of active Crohn's disease: results of the ENCORE Trial. Gastroenterology (2007) 132:1672-83. doi:10.1053/j.gastro.2007.03.024

49. Loftus EV, Colombel J-F, Feagan BG, Vermeire S, Sandborn WJ, Sands BE, et al. Long-term efficacy of vedolizumab for ulcerative colitis. J Crohns Colitis (2017) 11:400-11. doi:10.1093/ecco-jcc/jjw177

50. Vermeire S, Loftus EV, Colombel J-F, Feagan BG, Sandborn WJ, Sands BE, et al. Long-term efficacy of vedolizumab for Crohn's disease. J Crohns Colitis (2017) 11:412-24. doi:10.1093/ecco-jcc/jjw176

51. Lightner AL, Raffals LE, Mathis KL, Cima RR, Tse CS, Pemberton JH, et al. Postoperative outcomes in vedolizumab-treated patients undergoing abdominal operations for inflammatory bowel disease. J Crohns Colitis (2017) 11:185-90. doi:10.1093/ecco-jcc/jjw147

52. Dulai PS, Singh S, Jiang X, Peerani F, Narula N, Chaudrey K, et al. The realworld effectiveness and safety of vedolizumab for moderate-severe Crohn's disease: results from the US VICTORY consortium. Am J Gastroenterol (2016) 111:1147-55. doi:10.1038/ajg.2016.236

53. Kopylov U, Ron Y, Avni-Biron I, Koslowsky B, Waterman M, Daher S, et al. Efficacy and safety of vedolizumab for induction of remission in inflammatory 
bowel disease - the Israeli real-world experience. Inflamm Bowel Dis (2017) 23:404-8. doi:10.1097/MIB.0000000000001039

54. Stallmach A, Langbein C, Atreya R, Bruns T, Dignass A, Ende K, et al. Vedolizumab provides clinical benefit over 1 year in patients with active inflammatory bowel disease - a prospective multicenter observational study. Aliment Pharmacol Ther (2016) 44:1199-212. doi:10.1111/ apt. 13813

55. Targan SR, Hanauer SB, van Deventer SJ, Mayer L, Present DH, Braakman T, et al. A short-term study of chimeric monoclonal antibody cA2 to tumor necrosis factor alpha for Crohn's disease. Crohn's Disease cA2 Study Group. NEnglJ Med (1997)337:1029-35. doi:10.1056/NEJM199710093371502

56. Tew GW, Hackney JA, Gibbons D, Lamb CA, Luca D, Egen JG, et al. Association between response to etrolizumab and expression of integrin $\alpha \mathrm{E}$ and granzyme $\mathrm{A}$ in colon biopsies of patients with ulcerative colitis. Gastroenterology (2016) 150:477-87.e9. doi:10.1053/j.gastro.2015.10.041

57. Vermeire S, Ghosh S, Panes J, Dahlerup JF, Luegering A, Sirotiakova J, et al. The mucosal addressin cell adhesion molecule antibody PF-00547,659 in ulcerative colitis: a randomised study. Gut (2011) 60:1068-75. doi:10.1136/ gut.2010.226548

58. Vermeire S, Sandborn WJ, Danese S, Hébuterne X, Salzberg BA, Klopocka M, et al. Anti-MAdCAM antibody (PF-00547659) for ulcerative colitis (TURANDOT): a phase 2, randomised, double-blind, placebo-controlled trial. Lancet (2017) 390:135-144. doi:10.1016/S0140-6736(17)30930-3

59. Colombel J-F, Sands BE, Rutgeerts P, Sandborn W, Danese S, D'Haens G, et al. The safety of vedolizumab for ulcerative colitis and Crohn's disease. Gut (2017) 66:839-51. doi:10.1136/gutjnl-2015-311079
60. Drvarov O, AbuHashem R, Schunk N, Schreiber S, Kuehbacher T. Tu1346 skin and joint side effects in a subpopulation of anti-TNF experienced IBD patients, who respond to a treatment with vedolizumab, a humanized A4b7 integrin antibody. Gastroenterology (2015) 148:S-865. doi:10.1016/ S0016-5085(15)32933-4

61. Lissner D, Sonnenberg E, Glauben R, Allers C, Preiss J, Schneider T, et al P617 Extraintestinal autoimmune phenomena during treatment with vedolizumab. J Crohns Colitis (2017) 11:S394-5. doi:10.1093/ecco-jcc/ jjx002.741

62. Fuchs F, Schillinger D, Atreya R, Hirschmann S, Fischer S, Neufert CF, et al. Clinical response to vedolizumab in UC patients is associated with changes in integrin expression profiles. Front Immunol (2017) 8:764. doi:10.3389/ fimmu.2017.00764

Conflict of Interest Statement: SZ has received research support from Takeda and Hofmann-La Roche. EB and CW have no competing interests. BS served as consultant for Abbvie, Falk, Janssen, Hospira, MSD, and Takeda; received speaker's fees from Abbvie, Falk, Ferring, Hospira, Janssen MSD, and Takeda and a research grant from Pfizer.

Copyright $\odot 2017$ Zundler, Becker, Weidinger and Siegmund. This is an open-access article distributed under the terms of the Creative Commons Attribution License (CC BY). The use, distribution or reproduction in other forums is permitted, provided the original author(s) or licensor are credited and that the original publication in this journal is cited, in accordance with accepted academic practice. No use, distribution or reproduction is permitted which does not comply with these terms. 